\title{
HYDROCARBONS IN THE SÄVIÄ VOLCANIC SCHIST ZONE, CENTRAL FINLAND
}

\author{
K. RASILAINEN
}

\begin{abstract}
RASILAINEN, K. 1987: Hydrocarbons in the Säviä volcanic schist zone, central Finland. Bull. Geol. Soc. Finland 59, Part 2, 109-115.

Light hydrocarbon gases have been analysed from 21 samples of hydrothermally unaltered and 11 samples of hydrothermally altered metavolcanic rocks from the Säviä volcanic schist zone in the southwestern part of the Proterozoic VihantiPyhäsalmi-Pielavesi $\mathrm{Cu}-\mathrm{Zn}$ ore province, central Finland. The altered rocks are enriched in the lightest hydrocarbons (propanes and lighter) and depleted in the heavier hydrocarbons (butanes and heavier) compared with the metavolcanic rocks. The difference is clearest for methane (297.3 ppb in the altered rocks vs. $150.3 \mathrm{ppb}$ in the metavolcanic rocks), becoming less marked for the heavier hydrocarbons. A pre-metamorphic hydrothermal origin related to the alteration of the volcanic rocks is the most probable reason for the difference. It is suggested, in the light of the limited data available, that a negative methane anomaly (diameter about 8 $\mathrm{km}$ ) and positive cyclopropane and pentane anomalies (diameters about $2 \mathrm{~km}$ ) generated by ore forming processes exist around the Säviä $\mathrm{Cu}-\mathrm{Zn}$ deposit.
\end{abstract}

Key words: hydrocarbons, metavolcanic rocks, hydrothermal alteration, mineral exploration, Proterozoic, Säviä, Pielavesi, Finland.

K. Rasilainen: Geological Survey of Finland, Exploration Department, SF-02150 Espoo, Finland.

\section{Introduction}

The association of hydrocarbons with certain types of mineral deposit has long been known and studied (e.g. Bastin 1926; Pering 1973; Macqueen and Powell 1983). Most of this work has, however, concentrated on the visible, heavy hydrocarbons and pyrobitumens. Carter and Gazalet $(1984,1985)$ describe a method for exploration based on the analysis of trace amounts of light hydrocarbon gases in rocks. The method has revealed large anomalies, many kilometres across, around lead-zinc and copper deposits in the Lower Carboniferous rocks in Ireland.

This paper reports the results of a pilot study undertaken at the Säviä volcanic schist zone, central Finland, to examine the behaviour of hydrocarbon gases in a possible extinct geothermal zone and to evaluate the applicability of hydrocarbon analysis to exploration in highly metamorphosed igneous rocks of Precambrian age.

\section{General geology}

The Säviä schist zone is located in the southwestern part of the Proterozoic VihantiPyhäsalmi-Pielavesi $\mathrm{Cu}-\mathrm{Zn}$ ore province (Huhtala 1979) in central Finland (Fig. 1). The ore province is part of the Main Sulphide Ore Belt (Kahma 1973), which runs across Finland follow- 


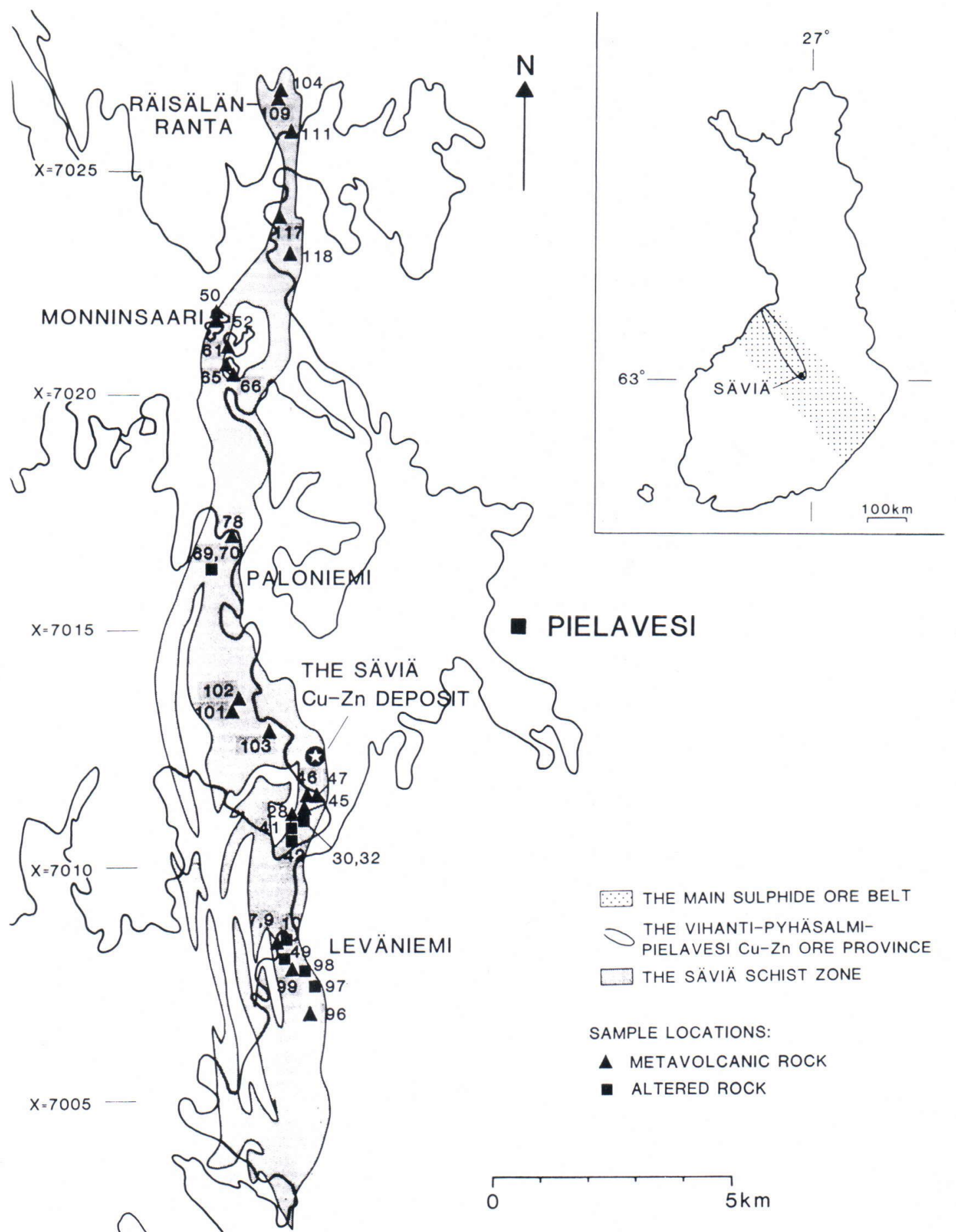

Fig. 1. Simplified map of the Säviä schist zone based on field studies and an aeromagnetic greytone map. 
ing the boundary zone between the Archean basement complex in the northeast and the Proterozoic Svecokarelian block in the southwest.

The roughly north-south trending Säviä schist zone consists mostly of metamorphosed mafic and intermediate volcanogenic rocks, but felsic volcanogenic rocks and detrital sediments are also present (Huhtala 1979). The zone is part of the Pielavesi block (Korsman et al. 1984), in which metamorphism reached granulite facies conditions. The Säviä $\mathrm{Cu}-\mathrm{Zn}$ massive sulphide deposit is located under a lake in the middle of the schist zone (Fig. 1).

The schist zone is surrounded by gneissose plutonic rocks, quartz diorites and trondhjemites, some of which are still recognizable as parts of the Presvecokarelidic basal complex (Huhtala 1979). Ages of $1924 \mathrm{Ma}$ and $1950 \mathrm{Ma}$ for the twostage model of Stacey and Kramers (1975) have been obtained for galenas from the Säviä $\mathrm{Cu}-$ $\mathrm{Zn}$ deposit and from a drill core sample of a cordierite gneiss at Jylhä, about $10 \mathrm{~km}$ north of Säviä. (Vaasjoki 1981).

According to Huhtala (1979), hydrothermal alteration expelled calcium and sodium from the volcanic rocks, and metamorphism resulted in the formation of sericite, cordierite and anthophyllite in the altered rocks. The altered horizon comprising garnet-cordierite-anthophyllite gneisses and rocks can be traced in outcrops from the southern end of the schist zone to Paloniemi, in the middle of the zone (Fig. 1). Volcanic activity closely related to the hydrothermal processes produced the Säviä $\mathrm{Cu}-\mathrm{Zn}$ massive sulphide deposit, which occurs in association with the altered rocks.

\section{Sampling and analytical methods}

The samples were chosen from those collected from outcrops in the course of a more extensive lithogeochemical study of the Säviä schist zone. The samples define a north-south trending profile along the schist zone, and their locations are given in Figure 1. Because of the scarcity of outcrops, large gaps remain in the profile. Altogether 32 samples were selected, 21 of which were metatuffs and 11 metamorphosed hydrothermally altered rocks.

The sampled metatuffs are mostly intermediate with abundant narrow mafic and felsic interlayers. The main minerals are plagioclase, hornblende, cummingtonite and quartz. Typical accessory minerals are biotite, apatite, zircon, magnetite, diopside and sericite. Diopside occurs as a main phase in some of the more mafic varieties. The altered rocks sampled are composed of varying amounts of garnet, cordierite, anthophyllite, quartz and plagioclase, with biotite, chlorite, opaque, apatite, zircon, sericite and sillimanite as the most common accessories. Their weathering surface is usually very uneven and the grain size grows from medium to coarse with diminishing plagioclase content.

Samples were taken from outcrops with a small portable drill. The diameter of the drill core was $2.5 \mathrm{~cm}$, and the length of individual samples sent for hydrocarbon analysis was about $10 \mathrm{~cm}$. Only macroscopically fresh pieces of the drill core were accepted, but because the sampling depth was less than $30 \mathrm{~cm}$ some weathering may have affected the samples. Before the analysis the surfaces of the samples were rubbed with sandpaper to remove any contamination from the drill bit, vegetation or some other source.

The samples were analysed for major elements and sulphur by X-ray fluorescence spectrometry, using pressed powders, at the Rautaruukki Oy laboratory, Raahensalo. The hydrocarbon analysis was carried out by gas chromatography at Mercury Hydrocarbons Ltd., Limerick, Ireland, using the method described by Carter and Gazalet (1985). Under standard conditions, 13 component gases are detected. The identity of five of these, among them the cyclopropane, acetaldehyde and formaldehyde components, is uncertain. Because of the rather poor precision of the method, from $20 \%$ to over $50 \%$ for most components, a duplicate analysis was made whenever 
possible, and the means of the two analyses for individual hydrocarbons were used in the study. For 12 samples, however, there was too little material for a second analysis.

\section{Results and discussion}

The means for major elements, sulphur and selected gases are given in Table 1. Acetaldehyde could be measured from only one sample (no. 111 in Fig. 1), which reflects its low concentration in the rocks. Contamination by organic matter is usually shown by high contents of all hydrocarbons and predominance of the formaldehyde, acetaldehyde and pentane components (Carter and Gazalet 1985). In this respect, there is no indication of contamination in the Säviä results. Plots of selected hydrocarbon contents are given in Fig. 2. Despite the poor precision of the method, the plots of the first and the duplicate analyses are very similar, but they are not given here.

Hydrocarbons are generated in sediments at low temperatures by biological and chemical reactions and at higher temperatures by thermal degradation of organic matter (Leythaeuser et al. 1983; Hunt 1984). Hydrothermal fluids (Welhan and Craig 1979; Burke et al. 1981) as well as igneous (Carmichael et al. 1974; Kadik and Lukanin 1985) and metamorphic (Fyfe et al. 1978; Collerson and Fryer 1978) fluids are known to contain light hydrocarbon gases. The complex hydrothermal and metamorphic history of the area prevents the origin of the hydrocarbons from being established solely on the basis of their quantities; nevertheless, hydrothermal activities and metamorphism certainly had a great influence on the hydrocarbon contents and ratios of the rocks.

There is a marked difference between the metavolcanic and altered rocks in major element and hydrocarbon contents (Table 1). The altered rocks are clearly depleted in sodium and calcium and slightly enriched in iron, magnesium and sulphur. Similar features commonly characterize the hydrothermally altered host rocks of many massive sulphide deposits (Govett 1983). The mean content of the lightest hydrocarbons (methane, ethane + ethene, propane + propene) is higher in the altered rocks, whereas the mean content of the heavier hydrocarbons (i-butane + n-butane + butene and pentanes + heavier) is higher in the metavolcanic rocks. The difference is clearest for methane (297.3 ppb in altered rocks vs. $150.3 \mathrm{ppb}$ in metavolcanic rocks), becoming less so for the heavier hydrocarbons.

All the hydrothermally altered samples from the Säviä zone have methane contents higher than $200 \mathrm{ppb}$, and all but four metavolcanic samples (nos. 50, 99, 109 and 111 in Fig. 1) have methane contents lower than $200 \mathrm{ppb}$ (Fig. 2). This suggests that methane could have potential as an index of hydrothermal alteration.

The southernmost of the four metavolcanic samples with high methane contents (no. 99, $237.4 \mathrm{ppb}$ ) is from south of Leväniemi, where

Table 1. Means and standard deviations of selected gases $(\mathrm{ppb})$, major elements and sulphur $(\%)$ for the Säviä rocks. Number of samples in brackets after column heading.

\begin{tabular}{|c|c|c|c|c|}
\hline & \multicolumn{2}{|c|}{$\begin{array}{l}\text { Metavolcanic } \\
\text { rocks }(21)\end{array}$} & \multicolumn{2}{|c|}{$\begin{array}{l}\text { Altered } \\
\text { rocks (11) }\end{array}$} \\
\hline & mean & std dev & mean & std dev \\
\hline methane & 150.3 & 77.0 & 297.3 & 78.5 \\
\hline ethane + ethene & 3.7 & 2.6 & 6.3 & 1.9 \\
\hline propane + propene & 7.7 & 3.3 & 11.0 & 3.5 \\
\hline cyclopropane & 2.0 & 1.7 & 1.9 & 1.4 \\
\hline butanes* & 49.7 & 28.1 & 23.6 & 10.3 \\
\hline pentanes + heavier & 26.5 & 19.6 & 16.7 & 5.2 \\
\hline formaldehyde & 22.3 & 13.0 & 14.4 & 4.5 \\
\hline acetaldehyde & 5.4 & - & - & - \\
\hline $\mathrm{SiO}_{2}$ & 58.64 & 6.85 & 58.93 & 7.87 \\
\hline $\mathrm{TiO}_{2}$ & 0.87 & 0.26 & 1.03 & 0.25 \\
\hline $\mathrm{Al}_{2} \mathrm{O}_{3}$ & 15.60 & 1.51 & 13.80 & 1.75 \\
\hline $\mathrm{FeO}_{\text {tot }}$ & 9.61 & 3.37 & 14.94 & 4.78 \\
\hline $\mathrm{MnO}$ & 0.17 & 0.05 & 0.16 & 0.07 \\
\hline $\mathrm{MgO}$ & 4.00 & 2.17 & 6.84 & 3.07 \\
\hline $\mathrm{CaO}$ & 5.46 & 2.45 & 0.63 & 0.30 \\
\hline $\mathrm{Na}_{2} \mathrm{O}$ & 3.73 & 0.96 & 1.03 & 1.42 \\
\hline $\mathrm{K}_{2} \mathrm{O}$ & 0.41 & 0.36 & 0.44 & 0.27 \\
\hline $\mathrm{S}$ & 0.18 & 0.18 & 0.37 & 0.47 \\
\hline
\end{tabular}

* i-butane + n-butane + butene 

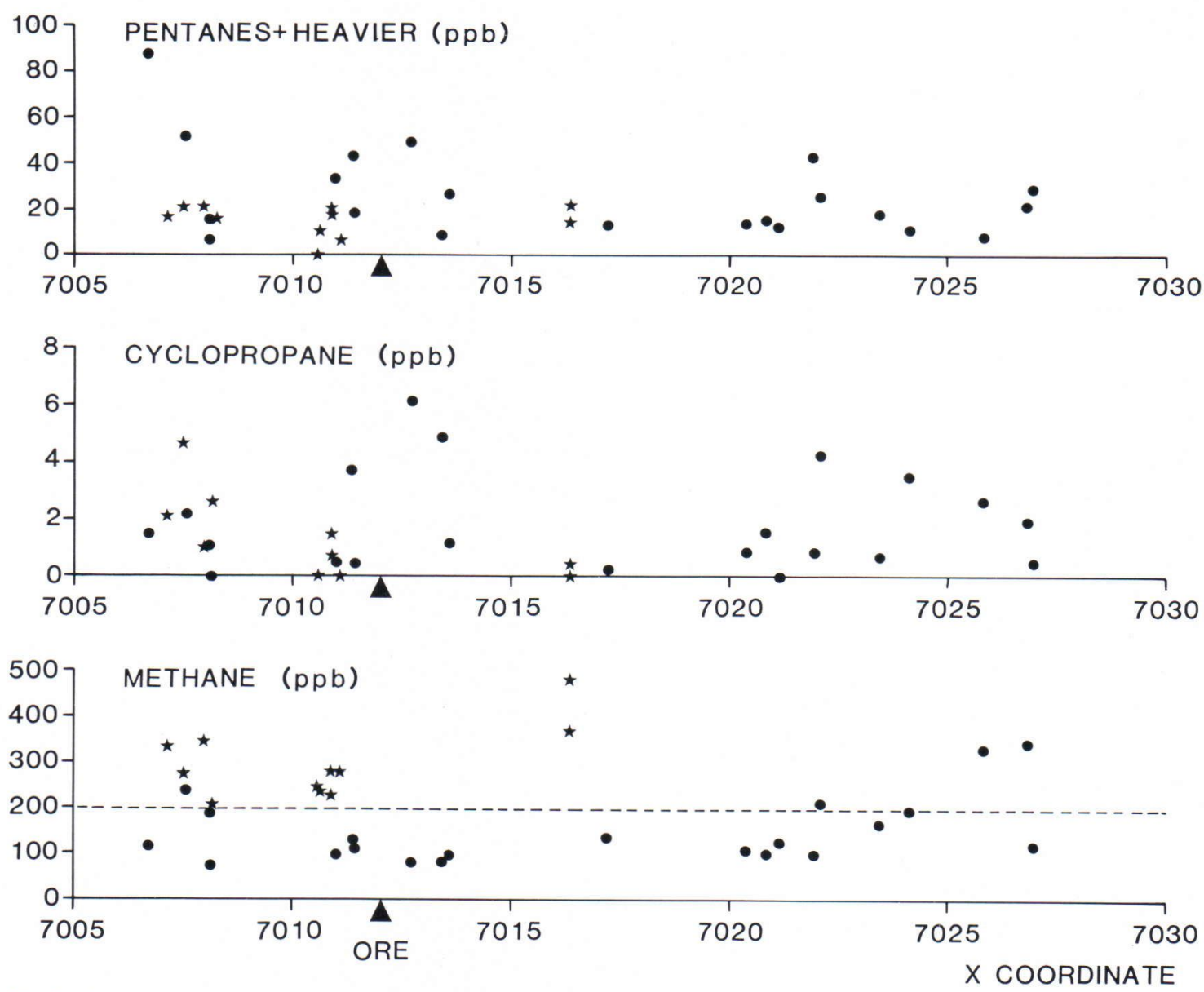

Fig. 2. Variations in the contents of selected hydrocarbons in the Säviä schist zone. Filled circle: metavolcanic rock, star: altered rock.

alteration has been intense. The other three samples (nos. 50, 109 and 111 with $212.6 \mathrm{ppb}$, $344.4 \mathrm{ppb}$ and $332.5 \mathrm{ppb}$ ) are from the northern part of the schist zone, where outcrops of altered rocks have not been found. Their high methane contents may be due to slight alteration, but a higher degree of metamorphism in the northern part of the schist zone could also have produced the high values by affecting the breakdown of heavier hydrocarbons. The southern end of the schist zone is located at the contact zone of the Pielavesi block with the Lampaanjärvi block, in which the degree of metamorphism is lower (Korsman et al. 1984); the northern parts, how- ever, are more clearly inside the Pielavesi block.

In the Lower Carboniferous rocks in Ireland, methane usually has a regional positive anomaly, several kilometres across, surrounding central concentrations of heavier hydrocarbons (pentanes + heavier) and cyclopropane in the vicinity of many $\mathrm{Pb}-\mathrm{Zn}$ deposits (Carter and Gazalet 1985). Because of the lack of outcrops, the number of samples is insufficient and their distribution unsuitable for giving a reliable picture of possible anomalies near the Proterozoic Säviä $\mathrm{Cu}-\mathrm{Zn}$ deposit. However, the cyclopropane and the pentanes + heavier components show positive anomalies with a diameter of about two 
kilometres around the deposit; they have high values elsewhere, too (Fig. 2). The distribution of methane is more difficult to interpret, but it suggests a large negative anomaly with a diameter of about eight kilometres around the deposit. The southernmost samples having high contents of cyclopropane and pentanes are located at Leväniemi and south of it, where alteration has been intense and where weak mineralization has occurred. The other samples with higher values of these components are from the northern parts of the schist zone, where no mineral deposits are known.

The distribution of the hydrocarbon gases suggests that two pre-metamorphic processes of different scale have affected the hydrocarbon contents of the rocks in the area. In exploration, it is important to differentiate between the results of these two processes. The difference in the level of hydrocarbon contents between the altered and the metavolcanic rocks can be attributed to a regional process of hydrothermal action that altered the volcanic rocks. The initial hydrocarbon contents of the hydrothermally altered rocks were most likely similar to those of other volcanic rocks. The rise in temperature caused by the hydrothermal fluids resulted in the break down of the heavier hydrocarbons into lighter hydrocarbons and led to relative depletion and enrichment in the altered rocks. The hydrothermal fluids may also have added some light hydrocarbon gases to the rocks. The hydrocarbon anomalies around the Säviä $\mathrm{Cu}-\mathrm{Zn}$ deposit, on the other hand, are probably the result of a more local ore-forming process. One possible mechanism for both hydrocarbon generation and sulphide precipitation could be sulphate reduction at the site of mineralization (Carter and Gazalet 1985).

Granulite facies metamorphism has certainly had a homogenizing effect on the hydrocarbon contents of the rocks, but it has not entirely wiped out the differences between the altered and the metavolcanic rocks or the hydrocarbon anomalies around the Säviä deposit. The hydrocarbon contents of rocks thus have potential in exploration, even in highly metamorphosed areas.

\section{Conclusions}

There is a difference in the hydrocarbon contents between the hydrothermally altered and the metavolcanic rocks. The difference is clearest for methane, becoming less so for the heavier gases. There were too few samples to give a reliable picture of the behaviour of the hydrocarbons in the vicinity of the Säviä $\mathrm{Cu}-\mathrm{Zn}$ deposit, but the data suggest the existence of a rather large negative anomaly of methane and smaller positive anomalies of cyclopropane and pentanes and heavier hydrocarbons around the deposit.

Two different pre-metamorphic processes are probably responsible for the distribution of hydrocarbon gases in the Säviä schist zone. Hydrothermal alteration of a regional nature has resulted in the enrichment of the lighter hydrocarbons and depletion of the heavier hydrocarbons in the altered rocks, whereas the oreforming process has generated the hydrocarbon anomalies around the Säviä deposit. For exploration purposes, it is important to distinguish between these two processes.

Granulite facies metamorphism has not been able to destroy either the difference in hydrocarbon contents between the altered and the metavolcanic rocks or the hydrocarbon anomalies around the Säviä deposit. This suggests that the hydrocarbon contents of rocks could be used in exploration in highly metamorphosed terrains, too.

Acknowledgements. I am grateful to N. Kärkkäinen, P. Nurmi and K. Puustinen for their comments on the manuscript. The figures were drawn by M. Kujala-Tammi. 


\section{References}

Bastin, E. S., 1926. A hypothesis of bacterial influence in the genesis of certain ores. J. Geol. 34, 773-792.

Burke, R. A.; Brooks, J. M. \& Sackett, W. M., 1981. Light hydrocarbons in Red Sea brines and sediments. Geochim. Cosmochim. Acta 45, 627-634.

Carmichael, I. S. E.; Turner, F. J. \& Verhoogen, J., 1979. Igneous Petrology. McGraw-Hill, New York, 739 p.

Carter, J. S. \& Gazalet, P. C. D., 1984. Hydrocarbon gases in rocks as pathfinders for mineral exploration. In Prospecting in areas of glaciated terrain 1984, Institution of Mining and Metallurgy, London, pp. 11-20.

—, \& Gazalet, P. C. D., 1985. The potential for using hydrocarbon gases in rocks as pathfinders for mineral exploration, vol. 1-2. Report on the work carried out at Mercury Hydrocarbons Ltd. for EEC CREST project "The role of light hydrocarbon gases in mineralization". Mercury Hydrocarbons Ltd., Limerick, Ireland, 101 p.

Collerson, K. D. \& Fryer, B. J., 1978. The role of fluids in the formation and subsequent development of early continental crust. Contrib. Mineral. Petrol. 67, 151-167.

Fyfe, W. S.; Prince, N. J. \& Thompson, A. B., 1978. Fluids in the earth's crust. Elsevier, Amsterdam, $383 \mathrm{p}$.

Govett, G. J. S., 1983. Rock Geochemistry in Mineral Exploration. Handbook of Exploration Geochemistry, Vol. 1, Elsevier, Amsterdam, 461 p.

Huhtala, T., 1979. The geology and zinc-copper deposits of the Pyhäsalmi-Pielavesi district, Finland. Econ. Geol. $74,1069-1083$.
Hunt, J. M., 1984. Generation and migration of light hydrocarbons. Science 226, 1265-1270.

Kadik, A. A. \& Lukanin, O. A., 1985. Mantle outgassing during melting: the role of carbon in fluid production in regions of basalt magma formation. Geochem. Int. 22, $25-35$.

Kahma, A., 1973. The main metallogenic features of Finland. Geol. Surv. Finland, Bull. 265, 28 p.

Korsman, K.; Hölttä, P.; Hautala, T. \& Wasenius, P., 1984. Metamorphism as an indicator of evolution and structure of the crust in Eastern Finland. Geol. Surv. Finland, Bull. $328,40 \mathrm{p}$.

Leythaeuser, D.; Schaefer, R. G. \& Pooch, H., 1983. Diffusion of light hydrocarbons in subsurface sedimentary rocks. AAPG Bulletin 67, 889-895.

Macqueen, R. W. \& Powell, T. G., 1983. Organic geochemistry of the Pine Point lead-zinc ore field and region, Northwest Territories, Canada. Econ. Geol. 78, 1-25.

Pering, K. L., 1973. Bitumens associated with lead, zinc and fluorite ore minerals in northern Derbyshire, England. Geochem. Cosmochim. Acta 37, 407-417.

Stacey, J. S. \& Kramers, J. D., 1975. Approximation of terrestrial lead isotope evolution by a two-stage model. Earth Planet. Sci. Lett. 26, 207-221.

Vaasjoki, M., 1981. The lead isotopic composition of some Finnish galenas. Geol. Surv. Finland, Bull. 316, 25 p.

Welhan, J. A. \& Craig, H., 1979. Methane and hydrogen in East Pacific Rise hydrothermal fluids. Geophys. Res. Lett. 6, 829-831.

Manuscript received December 17, 1986. 